\title{
Effective Molecular Monitoring and the Proper Management of Pleural Effusion During the First-Line Dasatinib Administration in CML
}

\author{
Salih AKSU, Ozlen BEKTAS, Burak UZ, Yahya BUYUKASIK, Nilgun SAYINALP, Osman OZCEBE, \\ Hakan GOKER, Ibrahim C. HAZNEDAROGLU
}

Hacettepe University Faculty of Medicine, Department of Hematology, Ankara, TURKEY

\begin{abstract}
Dasatinib is considered an effective treatment agent in imatinib-resistant and newly diagnosed chronic phase CML patients. Patients receiving dasatinib $100 \mathrm{mg}$ once daily regime suffered significantly fewer thrombocytopenia and pleural effusion events than those receving $70 \mathrm{mg}$ twice daily. Effective molecular monitoring and the proper management of pleural effusion during the first-line dasatinib administration in $\mathrm{CML}$ are essential. Pleural effusion may develop any time of the treatment and is easily managed by treatment interruption, dose reduction and supportive therapy. In this article, we intended to assess the rational of managing $C M L$ and pleural effusion that successfully managed with dose reduction and supportive care.
\end{abstract}

Keywords: Dasatinib, First-line therapy, Chronic myeloid leukemia, Pleural effusion

\section{ÖZET}

Kronik Myelositier Lösemide Birinci Basamak Tedavi Sırasında Oluşan Plevral Efüzyonun Yönetimi ve Etkin Moleküler İzlem

Dasatinib, imatinibe dirençli ve yeni tanı almış kronik faz KML hastalarında etkin bir tedavi ajanı olarak düşünülmektedir. Günde 100 mg tek doz dasatinib tedavisi alan hastaların günde 70 mg iki kez tedavisi alanlara göre anlamlı oranda daha düşük trombositopeni ve plevral efüzyon geliştirdikleri gösterilmiştir. KML'de moleküler monitörizasyonun dikkatli yapılması ve ilk sıra dasatinib verilen hastalarda plevral effüzyonun yönetilmesi büyük önem taşımaktadır. Plevral efüzyonun dasatinib tedavisinin herhangi bir zamanında ortaya çıkabilmekte ve doza ara verme, doz azaltma, ve destek tedaviler ile kolaylıkla yönetilebilmektedir. Bu çalışmada, KML ve plevral efüzyonun başarılla yönetimine ilişkin moleküler yöntemler araştırlacaktır.

Anahtar Kelimeler: Dasatinib, Illk-basamak tedavi, Kronik miyeloid lösemi, Plevral efüzyon 


\section{INTRODUCTION}

Dasatinib (SPRYCEL; Bristol-Myers Squibb, New York, NY) is a multi tyrosine kinase inhibitor (TKI), such as BCR-ABL, PDGFR- $\beta$, c-kit, and of SRC-family kinases ${ }^{1}$ and approved for first (approved in the US and Europe since 2010) and second line therapy in all phases of Chronic Myeloid Leukaemia (CML) (approved in the US and Europe since 2006). Dasatinib is also indicated for $\mathrm{Ph}$ positive-Acute Lymphoblastic Leukemia (ALL) and has good central nervous system penetration in managing $\mathrm{Ph}^{+}$intracranial leukemia. ${ }^{2}$

Dasatinib showed significant effi-cacy in patients with CP-CML who were resistant or intolerant to imatinib. ${ }^{3.4}$ According to two year follow up data of the START-C trial $(\mathrm{n}=387)$ indicated that overall CHR, MCyR, CCyR, and MMR rates were 91\%, $62 \%, 53 \%$, and $47 \%$, respectively. $88 \%$ of these pa-tients have maintained their MCyR at 24 months. The over-all survival (OS) and progression-free survival (PFS) rates were presented as $94 \%$ and $80 \%$, respectively. ${ }^{5,6}$ In CA180-034 dose-optimization random-ized study $(n=670), 100 \mathrm{mg}$ QD study arm showed similar efficacy results regarding CCyR (50 \% vs. $54 \%$ ), MCyR (63\% vs.61\%), PFS ( $80 \%$ vs. $76 \%$ ), and OS (91\% and $88 \%$ ) rates versus patients who received $70 \mathrm{mg}$ dasatinib BID at 24-month. ${ }^{7}$ OS at 60 -month was $78 \%$ and transformation to $\mathrm{AP} / \mathrm{BP}$ on study was $0 \%(\mathrm{n}=0){ }^{8}{ }^{8}$

In vitro, dasatinib has 325-fold greater pharmacologic potency than imatinib in unmutated BCR-ABL kinase. ' Dasatinib may improve response rates in the first-line therapy because the increased inhibition of BCR-ABL provides a better clinical respon$\mathrm{se}^{10}$ and dasatinib has resulted in high rates of CCyR and survival rates in second-line therapy of CML. ${ }^{48}$ The DASISION study (Dasatinib versus Imatinib Study in Treatment-Naive CML Patients) compared dasatinib and imatinib in the first-line treatment of chronic-phase CML and study results at 12-month indicated significantly higher and faster rates of CCyR and MMR. ${ }^{11}$ Dasatinib, $100 \mathrm{mg}$ daily, was also associated with a lower incidence of any-grade pleural effusion; fewer patients required dose interruption, dose reduction, and toxicity-related discontinuation in the second line usage. ${ }^{8} \mathrm{Ho}-$ wever, physicians may still think that dasatinib-tre- ated chronic myeloid leukemia patients are at risk for the development of pleural and pericardial effusions for the first-line treatment. In this paper, we would like to emphasize that pleural effusion occurring during dasatinib treatment is easily managed by treatment interruption and supportive therapy.

\section{MATERIALS, METHODS AND RESULTS}

The molecular study protocol was reviewed by the ethics committee. All patients gave written informed consent. BCR-ABL transcripts level assessment was performed by real-time quantitative polymerase chain reaction (RT-Q-PCR) according to suggested procedures and recommendations. BCRABL transcript levels were expressed as a percentage according to the IS, taking advantage of the ongoing international initiatives that allow researchers to standardize the quantitation of BCR-ABL transcripts through the use of a conversion factor and consequently to express their results according to the IS. The reference laboratories that performed most of the RT-Q-PCR analyses on this study and that were responsible for the validation of the results performed in central laboratory of DASISION. Representative samples were cross-checked in the laboratory. The materials, the reagents, and the methods that were used were developed within the international collaborative studies for the harmonization of BCR-ABL mRNA quantification.

Molecular technique has been applied to a representative CML patient. This typical patient was a 64-year-old Turkish female applied to our Hematology Clinic with leucocytosis which was detected during routine blood analysis. Her complete blood count $(\mathrm{CBC})$ showed hemoglobin $(\mathrm{Hb})$ of 12.7 $\mathrm{g} / \mathrm{dL}$ (normal range: 12.00-18.00), mean corpuscular volume (MCV) 85.6 fL (normal range: 80.00100.00). Her platelet count $\left(575 \times 10^{3} / \mu \mathrm{L}\right)$ (normal range: 150.00-450.00) and white blood cell count (WBC) were high $\left(89.8 \times 10^{3} / \mu \mathrm{L}\right)$ (normal range: 3.60-10.00) with $53.0 \%$ segmented neutrophils, $20.0 \%$ band neutrophils, $10.0 \%$ lymphocytes, $8.0 \%$ monocytes, $2.0 \%$ basophils, $2.0 \%$ metamyelocytes, $4.0 \%$ myelocytes, and $1.0 \%$ blasts. The biochemical assays revealed a mild increase in GGT (47 U/L [normal range: 5-36]) and uric acid $(7.48 \mathrm{mg} / \mathrm{dL}$ 


\begin{tabular}{|c|c|c|c|c|c|}
\hline 9556257 & 03-JUL-2008 & 7758 & 14262 & 0,81 & 44,06 \\
\hline 9556257 & 26-SEP-2008 & 4 & 2239 & 0,81 & 0,14 \\
\hline 9556257 & 30-DEC-2008 & 37 & 28536 & 0,81 & 0,11 \\
\hline 9556257 & 27-MAR-2009 & 17 & 25047 & 0,81 & 0,05 \\
\hline 9556257 & 22-JUN-2009 & 5 & 19932 & 0,81 & 0,02 \\
\hline 9556257 & 17-SEP-2009 & 1 & 6273 & 0,81 & 0,01 \\
\hline 9556257 & 16-DEC-2009 & 4 & 20307 & 0,81 & 0,02 \\
\hline 9556257 & 16-MAR-2010 & None Detected & 10013 & 0,81 & None Detected \\
\hline 9556257 & 16-MAR-2010 & 5 & 56862 & 0,81 & 0,01 \\
\hline 9556257 & 14-JUN-2010 & 2 & 18468 & 0,81 & 0,01 \\
\hline 9556257 & 10-DEC-2010 & 1 & 26406 & 0,81 & 0 \\
\hline 9556257 & 09-JUN-2011 & None Detected & 15442 & 0,81 & None Detected \\
\hline 9556257 & 09-JUN-2011 & None Detected & 13618 & 0,81 & None Detected \\
\hline 9556257 & 16-DEC-2011 & 1 & 18394 & 0,81 & 0 \\
\hline
\end{tabular}

[normal range: 2.4-5.7]) levels. LDH level was found to be upper than normal range (1245 U/L [normal range: 240-480]). On physical examination she was found to have hepatosplenomegaly.

The initial bone marrow biopsy in June 2008 revealed a hypercellular bone marrow with an increased ratio of miyeloid elements and fibrosis. Philadelphia chromosome $\mathrm{t}(9 ; 22)$ was positive in PCR analysis $(\mathrm{t}[9 ; 22] / \mathrm{G} 6 \mathrm{PDH}=0.3418)$, and also cytogenetical analysis was positive in all (20) metaphases for $\mathrm{t}(9 ; 22)(\mathrm{q} 34 ; \mathrm{q} 11)$. So, she was diagnosed as chronic phase chronic myeloid leukemia. She was than randomised to dasatinib arm of the DASISION Study on 05.07 .2008 at a dose of $1 \times 100 \mathrm{mg}$ /day peroral (po). After only 16 days of dasatinib treatment, she was accepted in complete hematologic remission. In 3 rd. month visit, the patient was in hematologic and cytogenetic complete remission, and bone marrow was normocelular with no reticulin fiber increment. Complete cytogenetic responce continued during 6th., 12th., 18th., 24th. and 36th. months, respectively. During the follow-up, the patient was monitored by quantitative real-time PCR (qRTPCR) (Table 1, Figure 1).

At 19th month of therapy, respiratory distress and grade 2 pleural effusion occurred under dasatinib. Dasatinib was stopped and diuretic treatment (spironolactone $1 \times 25 \mathrm{mg} /$ day, fluocortolone $1 \times 20$ $\mathrm{mg} /$ day peroral) was initiated. 16 days later, dasatinib $100 \mathrm{mg}$ /day was started. At 26th month of therapy, the patient reported respiratory distress and thorax CT revealed a grade 2 pleural effusion. Dasatinib was stopped and diuretic treatment (spironolactone 1 x25 mg/day, fluocortolone 1 x40 mg/day peroral) was initiated. Dasatinib 1x100 mg/day was started 23 days later. Under diuretic treatment pleural effusion declined from grade 2 to grade 1 , but dasatinib dose was reduced to $80 \mathrm{mg}$ in 2011 January. And finally, at 29th. month, grade 3 pleural effusion occurred. Dasatinib was stopped, and diure- 

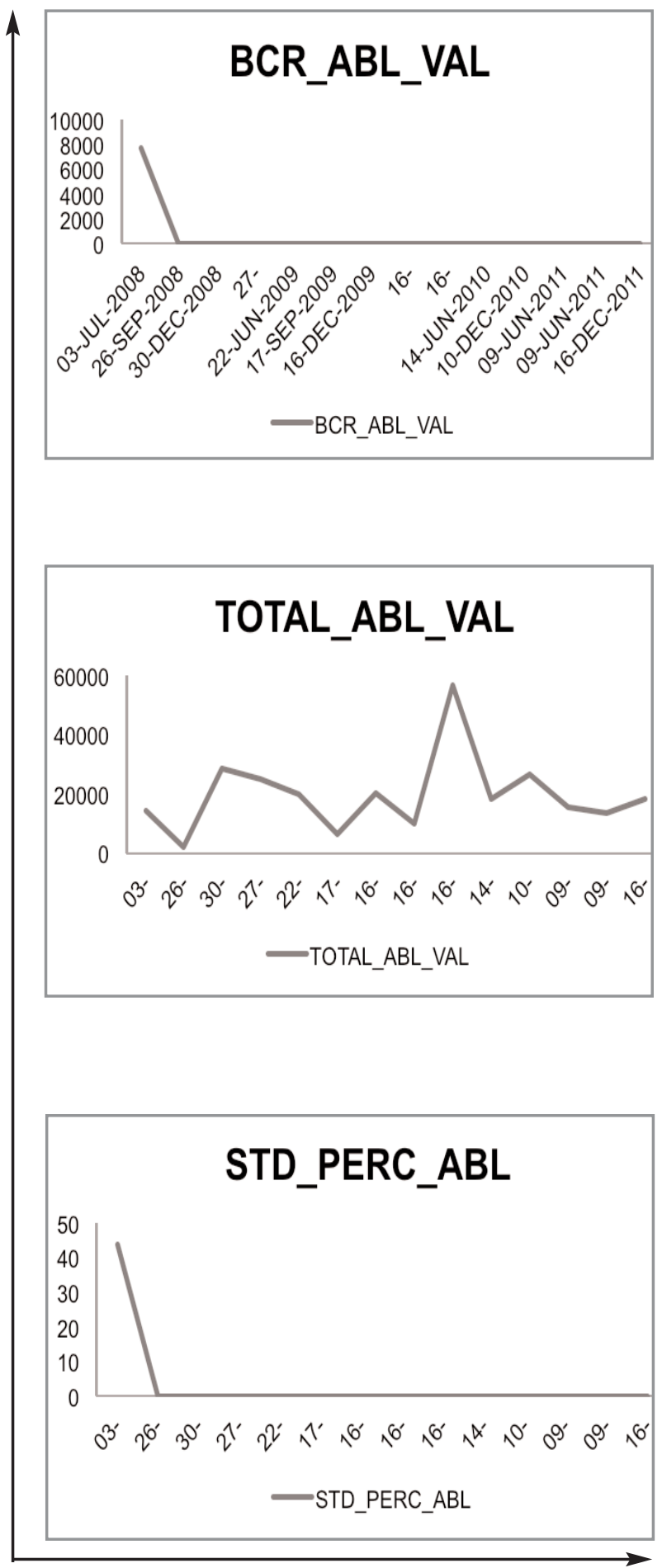

Figure 1. $B C R-A B L$ values of the $C M L$ patients during the administration of dasatinib tics were started again. Two weeks later, dasatinib was started at a dose of $70 \mathrm{mg} / \mathrm{day}$. The patients' last visit was on 2011 December. She had no respiratory distress, and was under dasatinib treatment at a dose of $70 \mathrm{mg} /$ day. Pleural effusion was accepted as grade 2. Also the patient had some other non-serious adverse events (arthralgia, neuropathy, and dry eye) during the treatment period (Table 2).

\section{DISCUSSION}

In this original research, we intended to assess the rational of managing CML and pleural effusion that successfully managed with dose reduction and supportive care. We observed that effective molecular monitoring and the proper management of pleural effusion during the first-line dasatinib administration in CML are essential. The representative patient with newly diagnosed chronic-phase CML has been treated with dasatinib, administered at a dose of $100 \mathrm{mg}$ once daily. She was accepted in hematologic and cytogenetic complete remission at the early stage of the treatment. The DASISION study showed superior efficacy including significantly higher of complete cytogenetic response ( $83 \%$ vs $72 \%$, $\mathrm{p}=$ 0.001 ) and major molecular response (46\% vs $28 \%$, $\mathrm{p}<0.0001)$ and faster rates $(\mathrm{p}<0.0001)$ for dasatinib $100 \mathrm{mg}$ once daily $(\mathrm{n}=259)$ compared with imatinib $400 \mathrm{mg}$ once daily $(\mathrm{n}=260)$ after 12 month follow up. ${ }^{11}$ In the longer follow up, patients treated by dasatinib and imatinib achieved CCyR ( $86 \%$ vs $82 \%$ ), MMR (64\% vs $46 \%$ ), CMR (17\% vs $8 \%$ ) and transformation to accelerated/ blastic phase CML (2.3\% vs $5.0 \%$ ), respectively. ${ }^{12}$ S0325 trial showed similar results with DASISON that dasatinib has deeper molec-ular responses (3-log reductions in BCR-ABL tran-script level) at 12 months compared with $400 \mathrm{mg}$ of imatinib (59\% vs. $43 \%$ ) in patients with newly diag-nosed CPCML. ${ }^{13}$ Overall, recent data showing superior efficacy of dasatinib versus imatinib in newly diagnosed CP-CML patients. In addition, NCCNv2.2012 panel recommends that second-generation TKIs may be an alternative treatment approach as a firstline therapy choice for all risk group of CML and especially for intermediate- to high-risk patients based on Sokal or Hasford score. Achievement of CCyR and/ or MMR within 12-month after the ini- 


\begin{tabular}{|c|c|c|c|c|c|c|}
\hline Adverse events & Seriousness & Onset Date & Resolution date & Grade & Relationship & Action \\
\hline Arthralgia & Non-serious & 05.07 .2008 & 26.09 .2008 & 2 & Probable & None \\
\hline Neuropathy & Non-serious & 20.09 .2009 & $\ldots$ & 1 & Possible & None \\
\hline Dry eye & Non-serious & 20.09 .2009 & $\ldots$ & 1 & Possible & $\begin{array}{l}\text { None, consultated to dep- } \\
\text { artment of ophthalmology }\end{array}$ \\
\hline $\begin{array}{l}\text { Pleural effusion and } \\
\text { respiratory distress }\end{array}$ & Serious & 22.02.2010 & 09.03 .2010 & 2 & Certain & $\begin{array}{l}\text { Drug was interrupted, } \\
\text { diuretics were used }\end{array}$ \\
\hline $\begin{array}{l}\text { Pleural effusion and } \\
\text { respiratory distress }\end{array}$ & Serious & 17.11 .2010 & 10.12 .2010 & 2 & Certain & $\begin{array}{l}\text { Drug was interrupted, } \\
\text { diuretics were used }\end{array}$ \\
\hline $\begin{array}{l}\text { Pleural effusion and } \\
\text { respiratory distress }\end{array}$ & Serious & 23.06.2011 & $\ldots$ & 3 & Certain & $\begin{array}{l}\text { Drug was interrupted, } \\
\text { diuretics were used. Two } \\
\text { weeks later, dasatinib was } \\
\text { started ( } 70 \mathrm{mg} / \text { day) }\end{array}$ \\
\hline
\end{tabular}

tiation of treatment was predictive of long-term treatment success regarding prolonged CCyR, very low risk of long-term progression, higher rate of OS, PFS, EFS and low risk for loss of CCyR..$^{14-18}$ Thus, achieving both a CCyR and MMR more quickly and at a higher rates should be an important treatment goal.

All grade of pleural effusion is frequent non-hematologic adverse event in dasatinib-treated patients. ${ }^{19}$ Although pleural effusion risk in patients treated with $100 \mathrm{mg}$ dasatinib once daily (14\%) was lower than patients receiving $50 \mathrm{mg}$ BID, $70 \mathrm{mg}$ BID, and $140 \mathrm{mg}$ once daily (23\% to $26 \%$ ) at 24-month follow up. ${ }^{7}$ In addition, only $2 \%$ of patients treated with dasatinib $100 \mathrm{mg}$ QD has been reported as grade 3 pleural effusion, with no grade 4 events, whereas grade 3 of 4 pleural effusion rates were $4 \%$ to $6 \%$ in other study arms. Rates at 24 months showed only a minimal increase compared with 12-month follow-up. Rates at 60 months showed only a minimal increase compared with 24-month followup. ${ }^{8}$ Recommendations for managing pleural effusion, are follows: after grade $2 \mathrm{AE}$, dasatinib is interrupted until the $\mathrm{AE}$ resolved, and then restarted at the original dose (100 mg QD); after recurrence of same grade $2 \mathrm{AE}$, dasatinib is interrupted and restarted at a reduced dose (80 $\mathrm{mg}$ QD); after second recurrence of the same grade $2 \mathrm{AE}$, dasatinib discontinuation can be considered by the investigator according to the best interests of the patient; after grade $3 \& 4 \mathrm{AE}$, dasatinib was interrupted until the $\mathrm{AE}$ resolved, and then restarted at a reduced dose; after recurrence of same grade $3 \& 4 \mathrm{AE}$, dasatinib discontinuation can be considered. Pleural effusions can be also managed by treatment interruption, dose reduction and supportive therapy. ${ }^{20}$ Porkka et al showed a possible correlation between pleural effusion and lymphocytosis ant the achievement of cytogenetic response with dasatinib treatment. ${ }^{21}$ In addition, patients with or without pleural effusion showed similar progression-free and overall survi$\mathrm{val}$, and cytogenetic response rates were higher in patients with a pleural effusion. ${ }^{21}$ Other studies have presented that patients with lymphocytosis during dasatinib treatment achieved favorable response rate ${ }^{22.23}$ and in parallel with this case report result.

In conclusion, pleural effusion may occur during dasatinib treatment and are generally grade II which can be easily managed by dose interruption, dose reduction, and supportive treatment such as diuretic/ steroids. Furthermore, serial molecular monitoring is the new standard of care in the management of CML. 


\section{REFERENCES}

1. Brave M, Goodman V, Kaminskas E, et al. Sprycel for chronic myeloid leukemia and Philadelphia chromosome-positive acute lymphoblastic leukemia resistant to or intolerant of imatinib mesylate. Clin Cancer Res 14: 352-359, 2008.

2. Porkka K, Koskenvesa P, Lundan T, et al. Dasatinib crosses the blood-brain barrier and is an efficient therapy for central nervous system Philadelphia chromosome positive leukemia. Blood 112:1005-1012, 2008.

3. Talpaz M, Shah NP, Kantarjian H, et al. Dasatinib in imatinib-resistant Philadelphia chromosome-positive leukemias. N Engl J Med 354:2531-2541, 2006.

4. Hochhaus A, Kantarjian HM, Baccarani M, et al. Dasatinib in-duces notable hematologic and cytogenetic responses in chronic-phase chronic myeloid leukemia after failure of imatinib therapy. Blood 109: 23032309, 2007.

5. Mauro MJ, Baccarani M, Cervantes F, et al. Dasatinib 2-year efficacy in patients with chronic-phase chronic myelogenous leukemia (CML-CP) with resistance or intolerance to imatinib (START-C). ASCO annual meeting, Chicago, IL, June 1-5, 2008 A7009.

6. Baccarani M, Rosti G, Saglio G, et al. Dasatinib time to and du-rability of major and complete cytogenetic response (MCyR and CCyR) in patients with chronic myeloid leukemia in chronic phase (CML-CP). 50. ASH annual meeting, San Fransisco, CA, December 6-9, 2008: A450.

7. Shah NP, Kim DW, Kantarjian H, et al. Potent, transient inhi-bition of BCR-ABL with dasatinib $100 \mathrm{mg}$ daily achieves rapid and durable cytogenetic responses and high transformation-free survival rates in chronic phase chronic myeloid leukemia patients with resistance, suboptimal response or intolerance to imatinib. Haematologica 95:232-240, 2010.

8. Saglio G., Cortes J E., Schiffer C A. et al. The longterm efficacy and saferty of dasatinib $100 \mathrm{mg}$ Once daily $(\mathrm{QD})$ in patients with imatinib resistant/ intolerant chronic-phase chronic myeloid leukemia: 5-year follow up from CA 180034. 16th Congress of the European Hematology Association (EHA), London, UK, June 9-12, 2011: P66.

9. O'Hare T, Walters DK, Stoffregen EP, et al. In vitro activity of Bcr-Abl inhibitors AMN107 and BMS- 354825 against clinically relevant imatinib-resistant Abl kinase domain mutants. Cancer Res 65: 4500-4505, 2005.

10. White D, Saunders V, Grigg A, et al. Measurement of in vivo $B C R-A B L$ kinase inhibition to monitor imatinibinduced target blockade and predict response in chronic myeloid leukemia. J Clin Oncol 25: 44454451, 2007.
11. Kantarjian H, Shah NP, Hochhaus A, et al. Dasatinib versus ima-tinib in newly diagnosed chronic-phase chronic myeloid leuke-mia. N Engl J Med 362: 22602270, 2010.

12. Kantarjian HM, Shah NP, Cortes JE, et al. Dasatinib or imatinib in newly diagnosed chronic-phase chronic myeloid leukemia: 2-year follow-up from a randomized phase 3 trial (DASISION). Blood 2: 119: 11231129, 2012.

13. Radich JP, Kopecky KJ, Kamel-Reid S, et al. A randomized phase II trial of dasatinib 100 mg vs imatinib $400 \mathrm{mg}$ in newly diagnosed chronic myeloid leukemia in chronic phase (CML-CP): the S0325 Intergroup trial 52. ASH annual meeting, Orlando, FL, December 4-7, 2010: LBA-6.

14. de Lavallade H, Apperley JF, Khorahad JS et al. Imatinib for newly diagnosed patients with chronic myeloid leukamia: incidence os sustained responses in an intention-to-treat analysis. J Clin Oncol 26: 33583363, 2008.

15. Quintas-Cardama A., Kantarjian $H$, Jones $D$ et al. Delayed achievement of cytogenetic and molecular response is associated with increased risk of progression among patients with chronic myleoid leukemia in early chronic phase receiving high-dose or standartdose imatinib therapy. Blood 113: 6315-6321, 2009.

16. Hughes T, Hochhaus A, Branford S, et al; IRIS investigators. Long-term prognostic significance of early molecular response to imatinib in newly diagnosed chronic myeloid leukemia: an analysis from the International Randomized Study of Interferon and STI571 (IRIS). Blood 116: 3758-3765, 2010.

17. Cortes J, Talpaz M, O'Brien S, et al. Molecular responses in patients with chronic myleoid leukemia in chronic phase treated with imatinib mesylate. Clin Cancer Res 11: 3425-3432, 2005.

18. Jacobucci I, Saglio G, Rosti G, et al. Achieving a major molecular response at the time of a complete cytogenetic response predicts a better duration of CCgR in imatinib-treated chronic myleoid leukemia patients. Clin Cancer Res 12: 3037-3042, 2006.

19. Talpaz M, Shah NP, Kantarjian H, Donato N, Nicoll J, Paquette $R$, et al. Dasatinib in imatinib-resistant Philadelphia chromosomepositive leukemias. N Engl J Med 354: 2531-2541, 2006.

20. Masiello D, Gorospe G, Yang AS. The occurrence and management of fluid retention associated with TKI therapy in CML, with a focus on dasatinib. J Hematol Oncol 2: 46, 2009.

21. Porkka K, Khoury HJ, Paquette RL, et al. Dasatinib $100 \mathrm{mg}$ once daily minimizes the occurrence of pleural effusion in patients with chronic myeloid leukemia in chronic phase and efficacy is unaffected in patients who develop pleural effusion. Cancer 116: 377-386, 2010. 
22. Mustjoki S, Ekblom M, Arstila TP, et al. Clonal expansion of T/NK-cells during tyrosine kinase inhibitor dasatinib therapy. Leukemia 23: 1398-1405, 2009.

23. Kim DH, Kamel-Reid S, Chang H, et al. Natural killer or natural killer/T cell lineage large granular lymphocytosis associated with dasatinib therapy for Philadelphia chromosome positive leukemia. Haematologica 94: 135-139, 2009.

\section{Correspondence}

\section{Dr. Salih AKSU}

Hacettepe Üniversitesi Tıp Fakültesi

iç Hastalıkları ABD, Hematoloji Ünitesi

Sihhiye, Ankara / TURKEY

Tel: (+90.312) 3051543

Fax: (+90.312) 3051614

e-mail: saksu@hacettepe.edu.tr 